\title{
ESCENARIO MULTICULTURAL: ECLECTICISMO DEL MUEBLE EN LA HABANA DEL SIGLO XIX A PARTIR DE REFERENTES CONSERVADOS EN MUSEOS DE LA CIUDAD
}

\section{MULTICULTURAL CONTEXT: ECLECTICISM OF FURNITURE IN NINETEENTH- CENTURY HAVANA BASED ON PIECES PRESERVED IN CITY MUSEUMS}

Indira Carrillo Álvarez*

Miembro de ICOM- Cuba

\section{Resumen}

Este artículo se propone demostrar cómo el contexto multicultural que se generó en Cuba en el siglo XIX, favorecido por los acontecimientos internacionales de la centuria precedente y por el Real Decreto de Libre Comercio de 1818, tuvo su expresión en el mobiliario adoptado o desarrollado en La Habana de la época. La aproximación se realiza desde el análisis integral de una selección de muebles de importantes colecciones conservadas en cinco museos habaneros: Museo de Arte Colonial, Casa de la Obra Pía, Museo de la Ciudad, Museo Municipal de Guanabacoa y Museo Napoleónico. Se analiza el comportamiento de las variables estilo, materiales y técnicas, con el empleo del método empírico de observación científica de las piezas y el auxilio del material de archivo disponible en las instituciones que conforman la muestra. Esta labor de interrelación permite un acercamiento a la procedencia geográfica e identificar improntas culturales en determinados muebles.

Palabras clave: Cuba, siglo XIX, mobiliario, cultura material, procedencia geográfica, colecciones museos habaneros

\section{Abstract}

This article aims to demonstrate how the multicultural context generated in Cuba in the 19th century, favored by the previous century's international events and by the Royal Decree of Free Trade of 1818, had its expression in the furniture adopted or developed in Havana of the time. The approach is made from the comprehensive analysis of a furniture selection from important collections conserved in five Havana museums: the Colonial Art Museum, the Museum Casa de la Obra Pía, the Museum of the City, the Municipal Museum of Guanabacoa and the Napoleonic Museum. The behavior of the style, materials, and techniques is analyzed using the empirical method of scientific observation of the pieces and the aid of the archive material available in the institutions that make up the sample. This interrelation allows an approach to the geographic origin and identifies cultural imprints on specific furniture pieces. 
Keywords: Cuba, 19th century, furniture, material culture, geographic origin, Havana museum collections

\section{Introducción}

La era de las revoluciones económicas, políticas y sociales vivió su esplendor en el siglo XVIII e irradió, a veces a destiempo, hacia todos los escenarios posibles. En términos culturales, dicha centuria se caracterizó por profundos cambios que marcaron nuevos horizontes en el ámbito internacional. Poderosas metrópolis del período, como España, Francia e Inglaterra, estuvieron entre las protagonistas de aquel escenario signado por acontecimientos y procesos, que repercutieron en la isla de Cuba, y de manera puntual en el moblaje. Por tal evidencia, el objetivo propuesto consiste en demostrar la pluralidad de procedencias e improntas culturales que se expresaron en el mobiliario en La Habana del siglo XIX.

Para ello se consideró oportuno, en un primer apartado, comentar aquellos sucesos internacionales relevantes que influyeron de alguna manera en el mobiliario en Cuba. En el segundo, se analizan piezas de cinco importantes museos habaneros que albergan significativas colecciones en el ramo, tanto desde una perspectiva cuantitativa como cualitativa: la Casa de la Obra Pía, el Museo de Arte Colonial, el Museo de la Ciudad, el Museo Municipal de Guanabacoa y el Museo Napoleónico. ${ }^{1}$ El amplio y variado panorama que reflejan estos exponentes adquiridos mediante transferencias, compras y donaciones, permite partir de la siguiente hipótesis: El mueble en La Habana del siglo XIX se distingue por el eclecticismo que resulta de un contexto cultural complejo y diverso que, tanto en el plano nacional como internacional, propició la inserción, adaptación y desarrollo de ejemplares de distintas procedencias geográficas.

En este estudio resultaron de gran utilidad el método histórico-lógico y el histórico-artístico para interpretar los hechos internacionales acaecidos desde el siglo XVIII, que influyeron en el contexto cubano y de forma específica tuvieron su expresión en el moblaje al interior de la Isla. Asimismo, fue empleado el método empírico de observación científica de las piezas, de conjunto con la revisión del material de archivo disponible en las instituciones que conforman la muestra.

\section{Panorama internacional y su repercusión en el devenir del mobiliario en la Isla}

Una mirada al ámbito del moblaje en la Cuba colonial, no debe obviar referentes precolombinos como el dujo, la hamaca y el coi estudiados, entre otros autores, por Lilia Martín Brito. ${ }^{2}$ El primero con carácter ritual y los dos últimos de naturaleza doméstica, constituyen un significativo aporte que pauta el inicio del desarrollo de este rubro en Cuba, conservándose aún en museos insulares puntuales ejemplos de dujo.

No obstante, a partir del siglo XVI se produjo el tránsito de los limitados muebles realizados por los aborígenes en la etapa precolombina - acordes 
con el desarrollo tecnológico alcanzado- hacia un mobiliario importado desde España, luego reproducido y adaptado en Cuba, que incorporó al enclave insular otros ejemplares realizados con materiales, técnicas y estéticas diferentes. En este sentido, los exponentes de origen español se caracterizaban por la rudeza, parquedad, rigidez y un exiguo número de piezas entre las que se introdujeron en Cuba el conocido bargueño ${ }^{3}$ - mejor denominado escritorio de Salamanca-, los bancos, el arraigado frailero dentro de la sillería y el armario. Este último es uno de los tipos de muebles incluidos en los dormitorios desde temprana data que permaneció durante el siglo XIX.

Así, al declarar la Corona española en 1589 a La Habana oficialmente capital de la Isla, desde ese momento tal condición privilegió el desarrollo de la urbe, entre otras razones, por el protagonismo que fue adquiriendo el intercambio mercantil a través de su puerto y por la prestancia que alcanzaron las edificaciones en las centurias siguientes. En materia de moblaje, España fue el modelo por excelencia hasta los albores del siglo XVIII. En 1700 fue instaurada la dinastía francesa de los Borbones en el trono español, al coronarse el duque Felipe de Anjou, nieto de Luis XIV, como Felipe V de España. De manera que esa influencia francesa arribaría a estas tierras gracias a la alianza familiar descrita con la presencia borbónica, tanto en la monarquía francesa como española, e irradiaría también al mobiliario.

El fortalecimiento de los vínculos entre estas dos metrópolis, expresado en los llamados Pactos de Familia, acentuó las rivalidades con Inglaterra; país este último que se insertaría en la historiografía cubana por otro hecho que también tuvo sus consecuencias en el ámbito comercial y propició la introducción de la huella inglesa en el moblaje: la toma de La Habana por los ingleses en 1762.

La ocupación inglesa de la ciudad durante once meses constituyó un llamado de alerta a la Corona española sobre la importancia comercial del puerto habanero; pues constituía un punto de escala necesario para el aprovisionamiento de las flotas reales en los viajes entre la metrópoli y sus colonias. Según afirman Ortega, Luguera y Alonso: "A mediados del siglo XVIII el comercio desde el puerto de La Habana se 1 mitaba a un pobre intercambio con Cádiz, Tenerife, Veracruz y Cartagena," además de otros territorios cercanos como Campeche, de donde se importaban sobre todo alimentos. Sin embargo, durante la dominación británica cesó el monopolio español en el territorio abriendo la brecha hacia el intercambio con Inglaterra y sus colonias.

En materia de muebles, esta apertura comercial favoreció la introducción de bienes provenientes de territorio francés, inglés y del norte de América de manera más notable desde finales del siglo XVIII. Asimismo, acentuó la importación de materiales de la zona del Caribe, como es el caso de la vaqueta de Campeche, posible origen de la denominación butaca de Campeche ${ }^{5}$ que recibe un tipo de asiento, presumiblemente masculino, utilizado durante siglos y muy semejante al butaque mexicano.

Un apartado merece la referencia a la impronta inglesa luego de 1762, pues los estilos Chippendale y Sheraton originados en Inglaterra durante el siglo XVIII también tuvieron su expresión tardía en Cuba. 
Los ebanistas cubanos se familiarizaron con las nuevas propuestas de diseño gracias a los libros de plantillas extranjeros, especialmente el de Thomas Chippendale titulado The Gentleman and Cabinet Maker's Director. Esta obra, impresa en 1754, tuvo una rápida difusión por el resto de Europa, Norteamérica y las colonias del Caribe. ${ }^{6}$

Además, Inglaterra estuvo implicada en otro acontecimiento de relevancia para la época: la lucha por la liberación de las Trece Colonias inglesas en América del Norte (1775-1783), que derivó en el reconocimiento de la independencia de los Estados Unidos de América. La cercanía geográfica de la nueva nación favorecería el intercambio mercantil con La Habana; hecho que se constata luego de que España recuperara la isla de Cuba e iniciara un comedido proceso de liberalización del comercio exterior en 1765.

Por otra parte, durante el reinado de Carlos III (1759-1788), promotor del Despotismo Ilustrado en la Isla, se implementaron una serie de reformas que favorecieron la evolución de la economía, entre las que pueden citarse el fomento del comercio intercolonial, la apertura de nuevos puertos en la metrópoli para el intercambio directo con sus colonias, y los eventuales autorizos en los años subsiguientes para el comercio con otras naciones, como es el caso de los Estados Unidos desde 1790. El mobiliario no quedó exento a este intercambio. En el número 255 de El Aviso. Papel Periodico de La Havana [sic] de 1807, en el apartado de Entrada de embarcaciones, se anunciaba la llegada de Boston de un bergantín con "...tablas y muebles de casa”. ${ }^{7}$

Por otra parte, el proceso emancipador protagonizado por las Trece Colonias sirvió de inspiración para los dominios en Hispanoamérica y precedería a otro hito en la historia de la humanidad: la Revolución Francesa de 1789. La revolución burguesa acontecida en Francia y las acciones posteriores que desencadenaría signaron el sentir de los hombres que habitaron ese tiempo. El llamado Siglo de las Luces, con el esplendor del pensamiento de la Ilustración, la caída del Antiguo Régimen o absolutismo monárquico en Francia, la Declaración de los Derechos del Hombre y del Ciudadano, luego la Revolución antiesclavista en Saint-Domingue (1791-1804), y las distintas campañas y empresas de Napoleón Bonaparte, fueron dictando el espíritu de una época y, con este, la sucesión de los estilos que también tuvieron su expresión en el mueble. La retroalimentación constante que se establece entre esta manifestación y el contexto en el que surge o se desarrolla, en algunos casos suele pasar inadvertida u opacada por el protagonismo concedido a otras expresiones artísticas. Sin embargo, el mueble, al surgir de necesidades inherentes al ser humano, entre las que se encuentra el descanso, es reflejo de los recursos de los que se dispone en cada época y de las características de sus propietarios o del período en general en el que se utilizaron.

Un ejemplo que por elemental no deja de ser fehaciente es la denominación conferida a estilos en correspondencia con los nombres de monarcas, como los afamados "Luises" franceses. Además, hay relación de los estilos con acontecimientos históricos, como es el caso de las campañas militares a Egipto reflejadas en el mobiliario de estilo Imperio impulsado por Napoleón Bonaparte en Francia, o luego la presencia de la Restauración en el propio país. Acorde 
con tales momentos y reinados, los exponentes reflejaban los preceptos que se postulaban en cada etapa, adoptando formas, motivos decorativos y estéticas peculiares en cada caso.

Este fenómeno acaeció con más fuerza en países como Francia, Inglaterra y España; pero también irradió hacia otros territorios fuera del entorno europeo. Precisamente, las oleadas migratorias de colonos franceses y algunos de sus esclavos procedentes de Saint-Domingue y la Louisiana, luego de la Revolución desatada en 1791, dejaron una huella indeleble en la cultura cubana en expresiones como la caficultura o la Tumba Francesa. En la materia concerniente a este estudio, el estilo Imperio con las aportaciones locales que se verifican en el dominio insular fue traído de aquellas tierras, pero a su vez atravesando las norteamericanas que impregnarían de sobriedad y funcionalidad al estilo destinado a vestir los espacios domésticos hasta mediados del siglo XIX aproximadamente.

De manera que el estilo o influencia estilística estuvo entre los elementos expresados en el mueble en Cuba que evidencian la repercusión de acontecimientos y tendencias foráneas. Además, en paralelo a los sucesos que en el orden socioeconómico y político se han citado en contextos nacionales; se produjo a escala internacional un proceso extendido en el tiempo que trajo al mundo aires de progreso en las esferas técnico-productivas: la Revolución Industrial.

La Revolución Industrial iniciada en Inglaterra hacia los años sesenta del siglo XVIII, y propagada con celeridad hacia sus colonias y el resto de Europa, aportó significativas invenciones en el ámbito tecnológico, además de su significación social por el empoderamiento de la burguesía y el surgimiento del proletariado como clase social antagónica. Las transformaciones que comenzaron por Inglaterra condujeron a considerarle el primer país que transitó de la variante manufacturera a la gran industria implementada mediante las maquinarias y la producción fabril.

En la esfera objeto de estudio, constituye un antecedente de la forma de producción industrial la Manufactura real de muebles de la Corona en la Francia del siglo XVII bajo el reinado de Luis XIV, más conocida como los Gobelinos por la fama de sus tapices. ${ }^{8}$ No obstante, la categoría de manufactura, que encabeza la denominación del establecimiento, se considera como una expresión muy incipiente al tratarse de un mercado hermético donde el beneficiario de los productos era el mismo poseedor del capital para desarrollarlos: el monarca. De manera que la labor de artesanos y artistas se dirigía a la decoración de palacios reales como Versalles o Saint-Germain.

El gran salto se produjo con la Revolución Industrial que, en muchos casos, vino a sustituir el procedimiento artesanal imperante por siglos en la elaboración de estos objetos, ante las presuntas ventajas de la producción mecanizada en términos de tiempo, esfuerzo físico y cantidades; en detrimento del valor estético que languidecía en los primeros exponentes realizados en serie. Ya en el marco temporal de la Segunda Revolución Industrial, iniciada a mediados del siglo XIX, se produce la Gran Exposición Industrial de 1851 en el Crystal Palace de Londres, inmersa en el esplendor del reinado de Victoria I.

Fue el primer evento con carácter internacional que, según Aquiles Gay y Lidia Samar: 
...ofreció la oportunidad de conocer y hacer un balance de la producción industrial de todas las naciones. Desde el punto de vista estético se hizo evidente la ausencia de armonía en los productos industriales, sobre todo en los de uso cotidiano, lo que provocó una reacción general que en la segunda mitad del siglo XIX se canalizó en la búsqueda de solución al problema de las relaciones entre arte, estética e industria. ${ }^{9}$

Para ese entonces, se ensalzaban sobre todo los artilugios ingeniosos y la novedad, aplicada también a los materiales y las técnicas. Así, en el ámbito del moblaje se expusieron productos en hierro, latón, zinc, papier mâché y mimbre, entre otros.

Asimismo, en el escenario de la exposición londinense se insertó un artesano ebanista de origen alemán, radicado en Viena, quien trascendió por los originales diseños precursores del Art Nouveau, alcanzados industrialmente mediante el perfeccionamiento de la técnica de la madera curvada al vapor: Michael Thonet (1796-1871). El diseñador, sintiendo predilección por la madera de haya europea (Fagus sylvatica), la sometía a baños de vapor con cola para favorecer su ductilidad y luego la introducía en prensas de bronce donde se definía la forma, dejaba enfriar y luego ensamblaba las partes mediante tornillos.

El procedimiento fue perfeccionándose al ampliar el mercado hacia climas tropicales, arribando a Hispanoamérica en la segunda mitad del siglo XIX. El éxito de este diseñador y de la empresa Gebrüder Thonet (Hermanos Thonet), constituida en 1853 bajo su égida - pero representada por sus cinco hijos- fue tal, que aún se producen y comercializan muebles de la compañía Thonet GmbH en diferentes regiones del mundo. A su vez, a finales de los años sesenta del siglo XIX se desarrollaron otras casas productoras que realizaban industrialmente muebles con madera curvada. ${ }^{10}$ Estos también arribaron acá, como lo reflejan anuncios de la época (Fig. 1) y ejemplares conservados en museos de La Habana y de Sancti Spíritus.

En términos económicos, la Revolución Industrial evidenció su impacto en el escenario nacional durante el siglo XIX. Así, importantes invenciones derivadas de este proceso, como la máquina de vapor y el ferrocarril, al introducirse en la Isla se pusieron al servicio del desarrollo económico, destacando como principal eslabón la industria azucarera. Sobre este particular, “...en el primer cuarto del siglo XIX, Cuba ocupaba el primer lugar como productora mundial de azúcar y, precisamente, la zona occidental de la isla tenía el 80 \% de la producción total". ${ }^{11}$

Se constata pues, cómo el protagonismo que en la centuria precedente ostentara Saint-Domingue en las producciones de azúcar y café, sería sustituido por Cuba, incorporando también la excelencia del tabaco cultivado desde etapas precedentes. Se consolidan así, las tres plantaciones principales de la economía agrícola del territorio, cuyos productos, y otros que se generaban en la Isla, participarían de la importante dinámica comercial que, sobre todo a través del puerto de La Habana, favorecería su exportación hacia mercados de los Estados Unidos y de Europa.

En relación con las importaciones, resulta pertinente referir el año 1818 como fecha que representó el momento cumbre de las franquicias comerciales 
que desde el siglo anterior se fueron concediendo a la colonia, pues para ese año se promulga el Libre Comercio a Cuba con los mercados de otros países por Real Decreto de Fernando VII. De modo que es durante el siglo XIX cuando se aprecia un intercambio más fluido de productos procedentes de diversos países, a través de distintos puertos, entre los que destaca el de la capital.

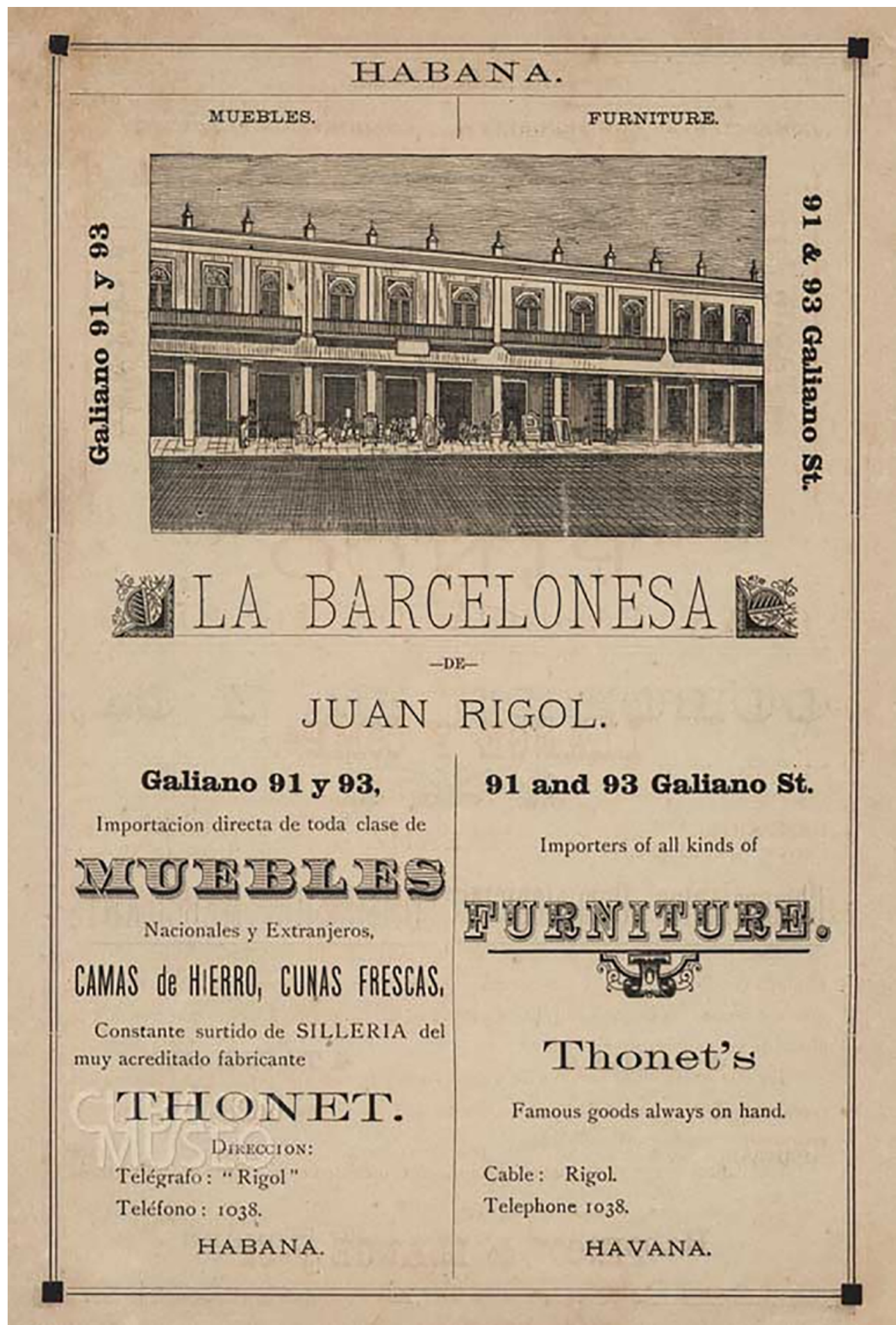

Fig. 1. Anuncio del Gran Almacén de Muebles La Barcelonesa de Juan Rigol sobre la importación de muebles y el surtido de sillería Thonet. Fuente: Directorio General para 1883-1884 de la Isla de Cuba. Habana: Centro Editorial de Obras Ilustradas de Molinas y Juli, 1883, s.p. 
Los muebles, el hierro labrado y las maderas se encontraban entre esos artículos que entraban y salían del puerto habanero, según datos rescatados por Alejandro de Humboldt concernientes a los años 1816 y 1823. De este último, se recogen las siguientes cifras:

Entre las mercancías y géneros importados: (...) hierro labrado, 288,697 duros; quincalla, muebles, cristales y porcelana, 464,328 duros; (...) tablas y otras maderas de carpintería 353,765 duros.

Entre los objetos exportados (...) muebles, cristles, quincalla, 8,046 duros; hierro labrado, 63,149 duros; tablas y maderas de carpintería 23,453 duros. ${ }^{12}$

El trasiego comercial permaneció en décadas siguientes y las maderas y muebles ocuparon un lugar importante entre los bienes que circulaban. Así, para el año 1859 se registra en pesos fuertes el valor de varios productos: "Los artículos que más figuraron en la importación de aquel año, como en los anteriores, fueron los siguientes: (...) Maderas 20,350 ps. fs.; Quincalla y mercería 470,219 ps. fs.; Muebles 99,418 ps. fs.; Metales $1.750,470$ ps. fs.”. ${ }^{13}$

De manera que las piezas y/o sus materiales podían partir y arribar de diversas naciones. Entre ellas, Estados Unidos se convirtió en uno de los más importantes agentes de los bienes que circulaban por el puerto habanero. De aquellas tierras llegaron los exponentes del diseñador John Henry Belter (1804-1863), del estilo Windsor, la variante norteamericana del estilo Imperio, y algunos de mimbre desde el último tercio del siglo XIX pues, además, se tiene constancia en La Habana de casas vendedoras de muebles y objetos decorativos norteamericanos.

Otro hecho importante finalizando la centuria, fue la intervención norteamericana en 1898, que constituiría la antesala para la instauración de la República en 1902. Respecto al moblaje, la presencia de los Estados Unidos ya se hacía latente desde etapas anteriores y dicho suceso vino entonces a reforzar los nexos existentes y a promover los estandartes de modernidad y progreso que favorecieron, entre otros avances, la profusión de las tecnologías sanitarias y los muebles vinculados a este servicio. ${ }^{14}$

Así, el período decimonónico cubano podría definirse como una etapa de esplendor económico, de efervescencia política, de modernidad, de profundos cambios en la imagen urbana y en la idiosincrasia de sus pobladores, entre los que destacan una aristocracia criolla ilustrada e informada, a tenor con las modas y conocimientos provenientes de otros lares, y una pujante burguesía que procura el control de la economía. La Habana estuvo entre los territorios privilegiados en vivenciar estas transformaciones.

En apretada síntesis, la conmoción que en materia política y socioeconómica distinguió el panorama internacional de la segunda mitad del siglo XVIII, favoreció una serie de cambios que delinearon el escenario de las décadas siguientes. En el ámbito del mobiliario en Cuba, las condiciones fueron propicias para su desarrollo y diversificación. La variedad de referentes foráneos, la riqueza económica de la colonia, aupada en gran medida por el esplendor de la plantación azucarera, y la existencia de clases dominantes que gustaban del 
lujo, la ostentación y la comodidad de sus viviendas, favorecieron el auge de un mobiliario de probados valores estéticos y funcionales, testigos hoy de una época de esplendor.

\section{Presencia e impronta foránea en el mobiliario conservado en museos habaneros}

En Cuba y más en La Habana existen numerosos museos que procuran rescatar, recrear y transmitir, a través de salas ambientadas y salas temáticas, el patrimonio material e inmaterial de épocas pasadas. El mobiliario es una de esas expresiones de la cultura material que protagoniza los espacios expositivos de estas instituciones y posibilita la aproximación a un tiempo pretérito. En este sentido, el siglo XIX en el contexto insular fue prolífico, en parte por los ecos de los acontecimientos internacionales que se sucedieron desde décadas anteriores y, a su vez, por el auge económico al interior de la Isla sustentado en una férrea esclavitud.

En el ámbito social, en la base de la pirámide se hallaría el negro esclavo, en el escaño cercano a la cúspide la burguesía y en la cima la aristocracia, los dos grupos sociales que proyectaban su estatus de riqueza de todas las formas posibles gracias a la explotación esclavista. Sobre estos altos estratos resumiría la historiadora Alicia García Santana:

...una nueva y poderosa clase social, la oligarquía local, que se interesa por su ciudad, sus calles y servicios, los lugares de expansión pública; que le importa el prestigio de la casa que habita, el linaje de la familia, el ritual de la vida doméstica, el adorno del vestido, la comodidad de sus muebles, la calidad de la comida, las nuevas en materia de literatura, historia y ciencias; que se siente parte del mundo en que vive, en el cual se proyecta y, por tal, asume como el reflejo de sí. ${ }^{15}$

Así la oligarquía criolla, preocupada desde etapas anteriores por una esmerada educación que le permitiría escalar escaños en las esferas administrativa, política y social de la colonia, manifestaba un gusto tendiente al eclecticismo. Ello se expresaría tanto en las edificaciones, originarias en no pocas ocasiones de siglos precedentes, adaptadas al estatus de la familia y necesidad de uso, como en el lujo y las ambientaciones de los espacios interiores donde podían encontrarse habitaciones decoradas con objetos de estilo (Fig. 2) procedentes de diferentes territorios y períodos.

En este sentido, la impronta española estuvo presente desde temprana data y muchos de los exponentes legados o sus reproducciones y adaptaciones en la Isla acompañaron las estancias habaneras durante varios siglos gracias a la solidez y funcionalidad de los ejemplares. Una de las tipologías que arribaron desde España y permanecieron en las ambientaciones habaneras en el siglo XIX fueron los escritorios de Salamanca (Fig. 3).

Popularizado en la comunidad de museólogos cubanos y de otros países con el nombre de bargueño, este escritorio con tapa abatible y pie de puente está compuesto por nogal (Juglans regia) tallado y hierro forjado en su exterior; 
mientras que en el interior presenta numerosos cajones con elaboraciones en taracea de hueso pintado, columnillas salomónicas decorativas también realizadas en hueso y tiradores de madera en forma de bellota. Es una pieza única en la colección del Museo de Arte Colonial y existen otros exponentes de esta tipología en el Museo de la Ciudad.

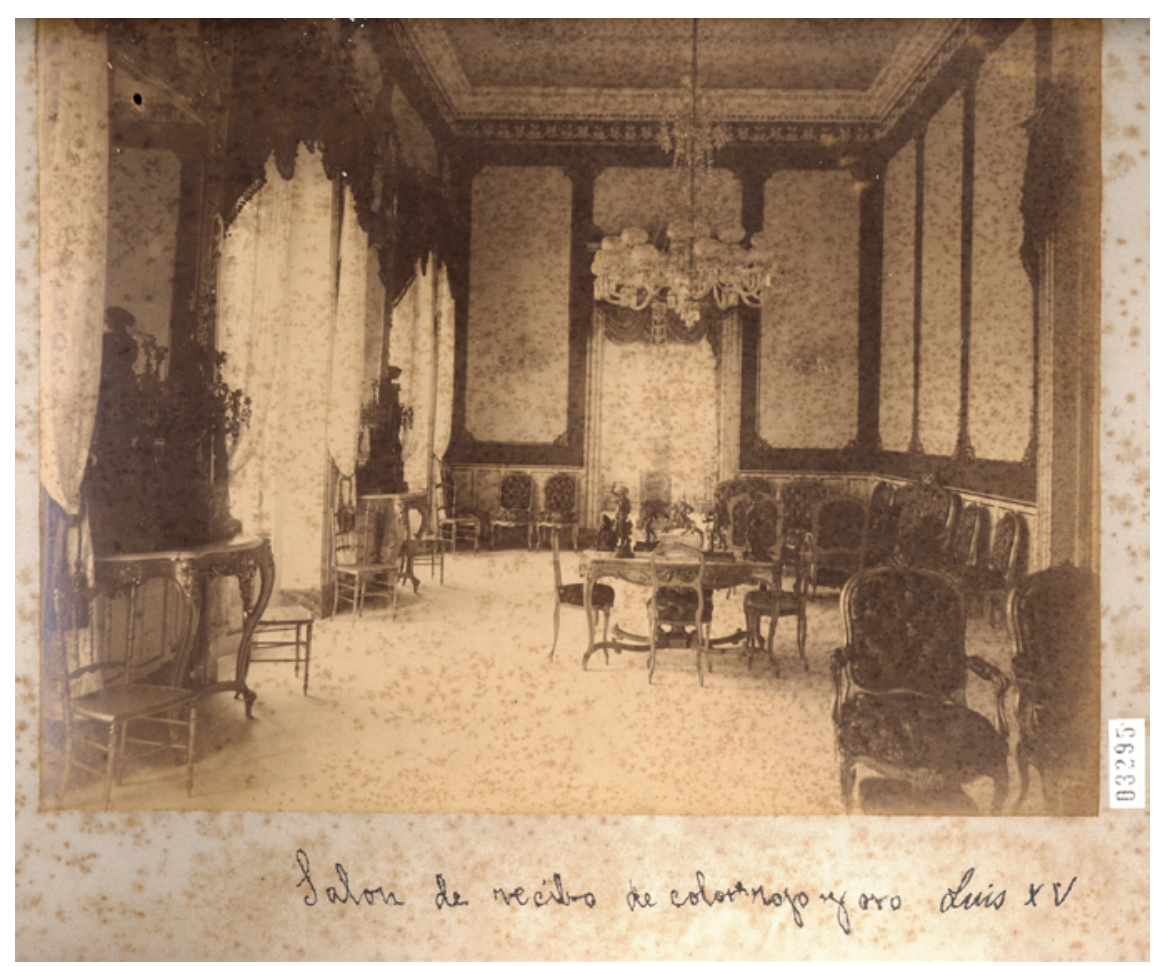

Fig. 2. Salón de recibo de color rojo y oro Luis XV. Casa de los Marqueses de Balboa. La Habana, s. XIX. Fuente: Fototeca Histórica de la Oficina del Historiador de La Habana (OHC)
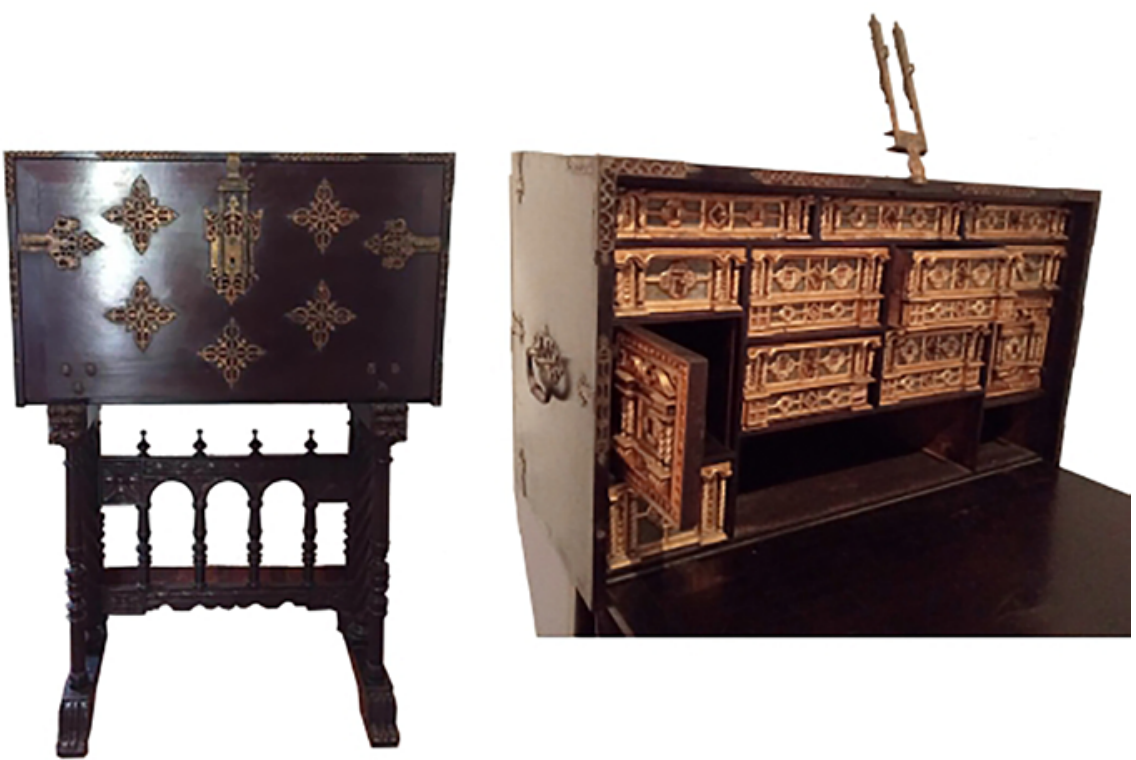

Fig. 3. Escritorio de Salamanca cerrado y abierto. España, s. XVII. Col. Museo de Arte Colonial 
Sin embargo, la presencia española no consiste solo en las piezas introducidas paulatinamente que durante el siglo XIX y con posterioridad han pervivido en hogares o instituciones museales. También, la huella está en aquellos tipos de muebles que se importaron desde la metrópoli y que fueron copiados o adaptados a estas condiciones por los carpinteros de ribera, que laboraban vinculados al puerto, al tiempo que perfeccionaban sus habilidades en el oficio de la ebanistería. Se trata, por ejemplo, de los armarios o escaparates, el sillón frailero, y de los arcones, cajones o cajas de cedro de La Habana, ${ }^{16}$ denominación con la que se popularizaron en el área latinoamericana. Estas primeras piezas que denotan la huella de España en los siglos iniciales de la colonia están representadas en una de las salas temáticas dedicadas al mobiliario en el Museo de Arte Colonial. No obstante, se estima que estos ejemplares realizados en su mayoría en cedro (Cedrela odorata) y caoba (Swietenia mahagoni), recuperados del antiguo Convento de Santa Clara en La Habana, son muestras autóctonas realizadas a partir de referentes incorporados por España.

En otro orden, no se debe obviar el importante rol de los peninsulares que se trasladaron a Cuba y desarrollaron aquí sus comercios, en este particular, asociados a la producción y comercialización de estos bienes fabricados en territorio insular o en el extranjero. Aunque existen numerosos casos, se considera oportuno destacar el promovido por los Sres. Borbolla, de procedencia española. Ejemplo de ello es el mueble lavabo (Fig. 4) que se exhibe en la Casa de la Obra Pía como parte de un juego de cuarto ecléctico.
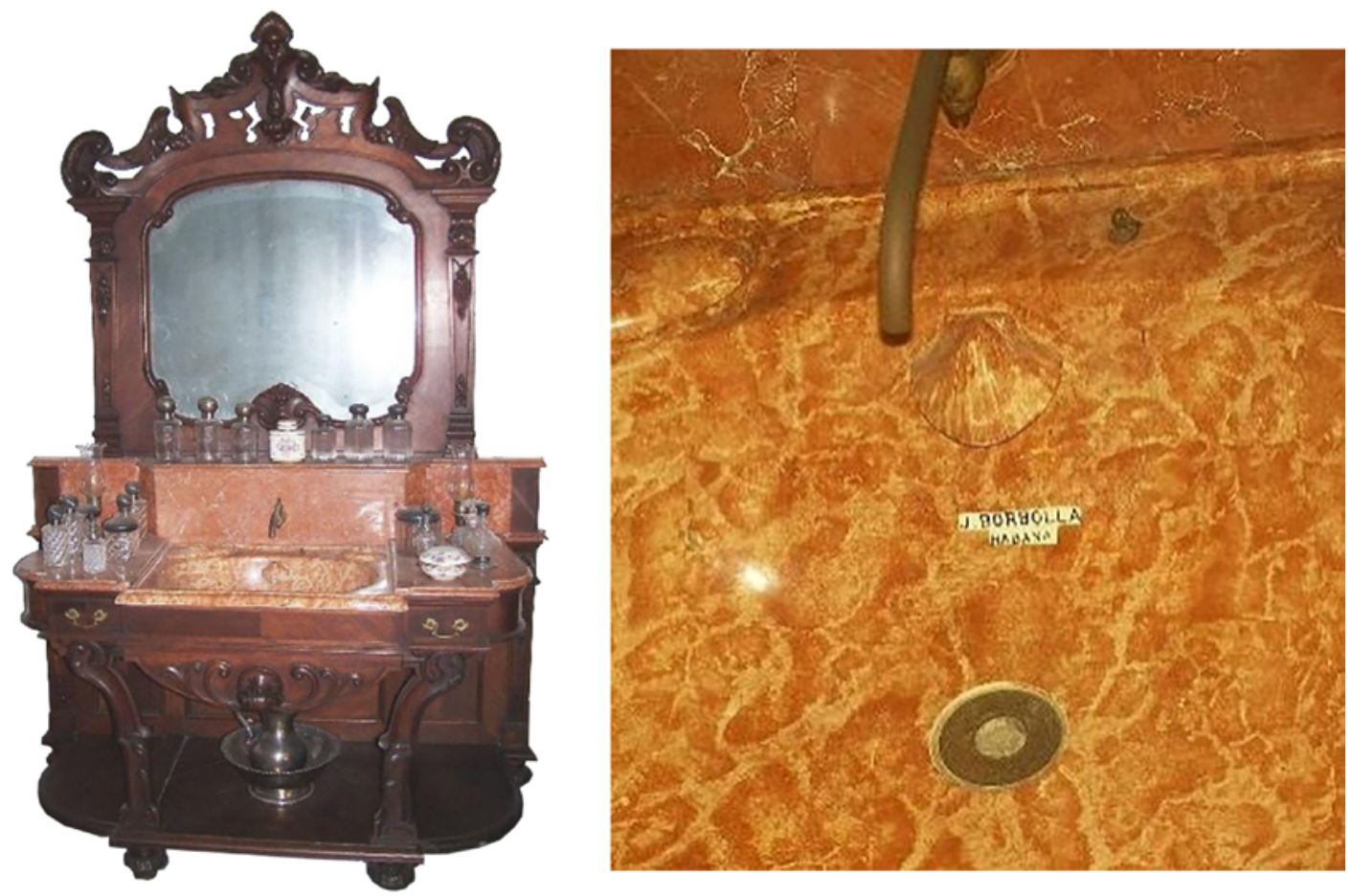

Fig. 4. Mueble lavabo y detalle de la marca de fabricante J. Borbolla Habana. Cuba, finales s. XIX-principios s. XX. Col. Casa de la Obra Pía 
Un análisis para la identificación de las maderas en este y los restantes muebles del dormitorio ambientado de dicho museo, a través del método de anatomía comparada, ${ }^{17}$ arrojó la presencia de cedro y caoba, además de presentar áreas en loza, mármol, bronce y cristal. Respecto a las técnicas, sobresalen el enchapado, la incisión y la talla en alto y bajorrelieve.

En específico, en la zona del lavamanos se aprecia el sello J. Borbolla Habana, marca de fabricante que también se encuentra en un ejemplar similar del Museo de la Ciudad y que tenían los productos realizados en La Casa Borbolla. Este establecimiento al parecer tuvo mucho éxito y larga vida en el tiempo. Sobre sus antecedentes en el XIX y esplendor a principios de la centuria siguiente se cita fragmento de una entrevista al poeta cubano Eliseo Diego, hijo del asturiano Don Constante de Diego González. Este último llegó a Cuba alrededor de 1900 y pasados unos años se convirtió en propietario de La Casa Borbolla cuando se encontraba en las calles San Rafael y Galiano:

...mi padre era dueño de una mueblería, joyería y casa de antigüedades. Este comercio de mi padre fue muy famoso a principios de siglo, y hasta los años veinte, se llamaba La Casa Borbolla. Mi padre era asturiano. Vino a Cuba a la edad de quince años, y empezó a trabajar en esta mueblería, cuyo dueño era también un asturiano de apellido Borbolla. Cuando murió, este hombre no tenía herederos. Quería mucho a mi padre y mi padre se quedó al frente del negocio. ${ }^{18}$

De modo que, con esta declaración, Eliseo corrobora la existencia del comercio de los Borbolla (Fig. 5) desde el siglo XIX y el origen español de sus diferentes dueños que, sin dudas, aportaron al moblaje de residencias e instituciones desde entonces.

\section{EL HOGAR}

\section{iGBANDES NOTEDADES! IESPLEDIDO SURTIDO! \\ COMPOSTELA $54,56 \mathrm{Y}$ 60, ENTRE OBRAPIA Y LAMPARILLA. LA CASA DE LOS SRES. J. BORBOLLA Y COMP.

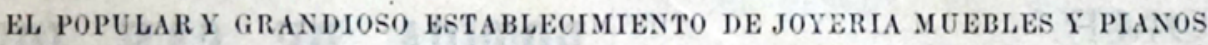 LA AMERICA}

ha reforzado el gran surti to de joy as que ostentaba en sus ricos anaqueles, con nuevas facturas recibidas de Paris y todo lo realiza á precios fabulosamente baratos - Dormilonas, pulseras, prendedores, sortijas, sderezos completos con brillantes, perlas zaflros y demás piedras de moda. Relojes, leontimas, bastor e3, carteras, perfumadores y otros mil objetos propios para regalos. Muebles.-Kealizamos todos los que existen en nuestros ámplios almacenes á precios baratísimos. En la fábrica que hemos establecido, hacemos toda clase de muebles finos y corrientes, á gusto del consumidor y a precios equitativos. Pianos de Pleyel nuevos y de otros fabricantes europeos de gran fama. Tenemos en camino una gran factura de pianos de Boisselotfils y ca. de Marsella. Compramos oro, plata, brillantes y otras pied.as tinas en todas cantidades, así como muebles y pian.ss... Se alquilan pianos. - Telefono 298. - A partado 457.-Cable: Borbolla.

Fig. 5. Anuncio de los Sres. J. Borbolla y Comp. Establecimiento de joyería, muebles y pianos La América. Fuente: El Hogar. Periódico de las familias, no. 3, Habana, 15 de enero de 1888, p. 9. 
Del Viejo Continente también arribaron a Cuba exponentes de estilo en puridad, fundamentalmente procedentes de Francia, que engalanaron los salones de las mansiones en La Habana decimonónica. Es el caso del conjunto Luis XVI (Fig. 6) que se exhibe en el Museo de la Ciudad. Los ejemplares de madera laminada en oro se hallan decorados con ornamentos vegetales tallados en los reposabrazos, al centro del faldón y del respaldo, estos últimos con dos ramas entrecruzadas y unidas al centro por una lazada.
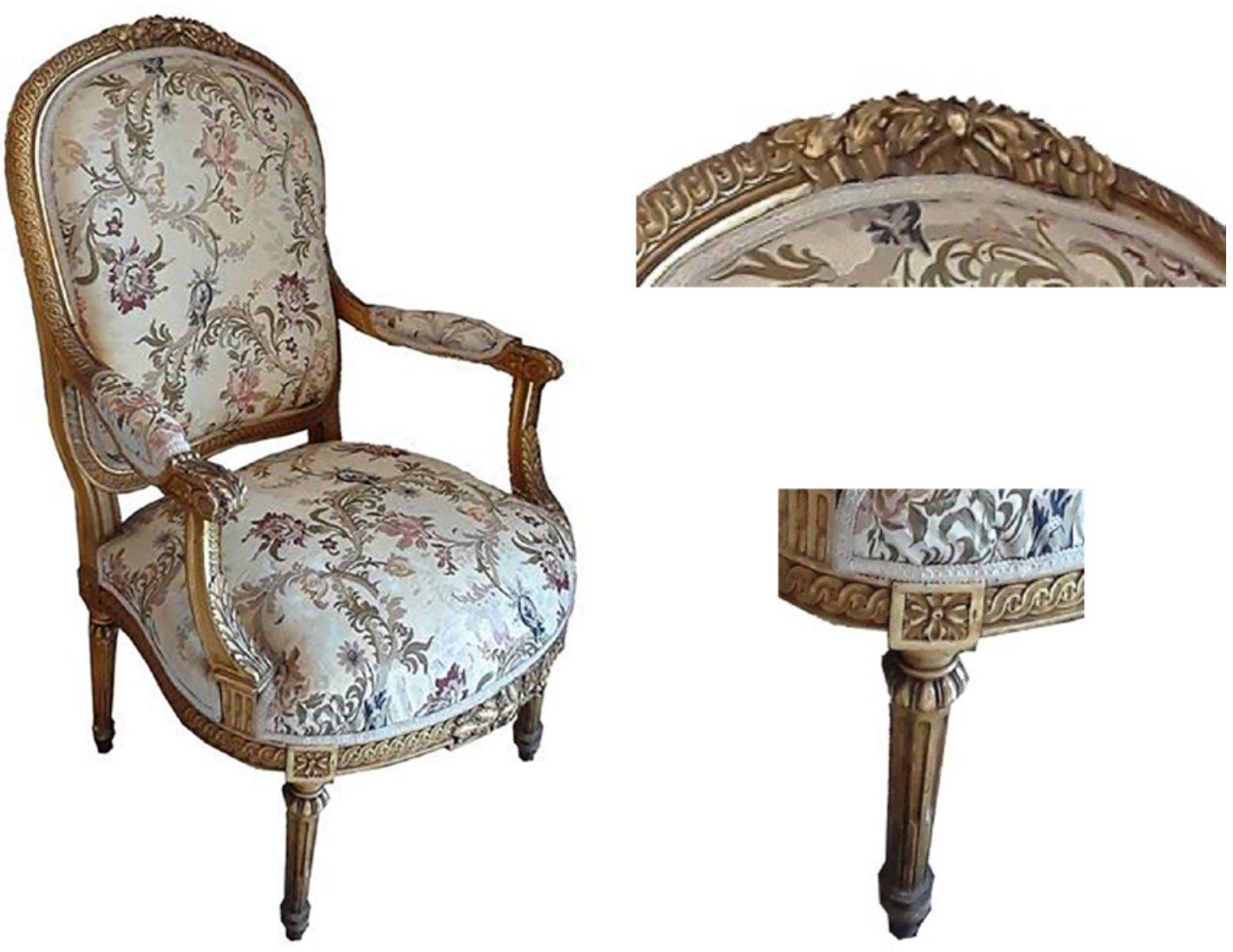

Fig. 6. Butaca Luis XVI con detalles de ornamentación vegetal en el coronamiento del respaldo y dado de unión con motivo floral sobre pata acanalada. Francia, finales s. XVIII. Col. Museo de la Ciudad

Además, presentan motivos decorativos a modo de cenefa con cintas entrelazadas que enmarcan el tapizado, tanto del asiento como del respaldo. Se pueden apreciar las patas rectas y estriadas o acanaladas que se ensamblan al asiento mediante un dado con el ornamento en forma de rosa, frecuente en este estilo. Los reposabrazos lucen almohadillas y el tapizado original fue sustituido en 1997. No obstante, las piezas poseen un valor añadido, ya que fueron donadas a la institución por la afamada poetisa y novelista cubana Dulce María Loynaz (1902-1997).

Asimismo, el mobiliario que viste las diferentes estancias del Museo Napoleónico ${ }^{19}$ en el barrio capitalino del Vedado es de procedencia francesa en su mayoría. Se trata de una colección singular en el marco de este estudio, pues 
la edificación que resguarda los fondos, y Julio Lobo Olavarría (1898-1983), el llamado Zar o Rey del Azúcar poseedor de estos bienes, se inscriben en el siglo XX. No obstante, gran parte de los muebles data del siglo XIX y refleja ambientaciones a la usanza de la burguesía francesa de dicha centuria, con fieles exponentes del estilo Imperio francés. Con anterioridad estas piezas formaban parte de la ambientación general de la residencia (Fig. 7) de Julio Lobo, quien dedicó parte de su fortuna a coleccionar objetos de la época napoleónica.

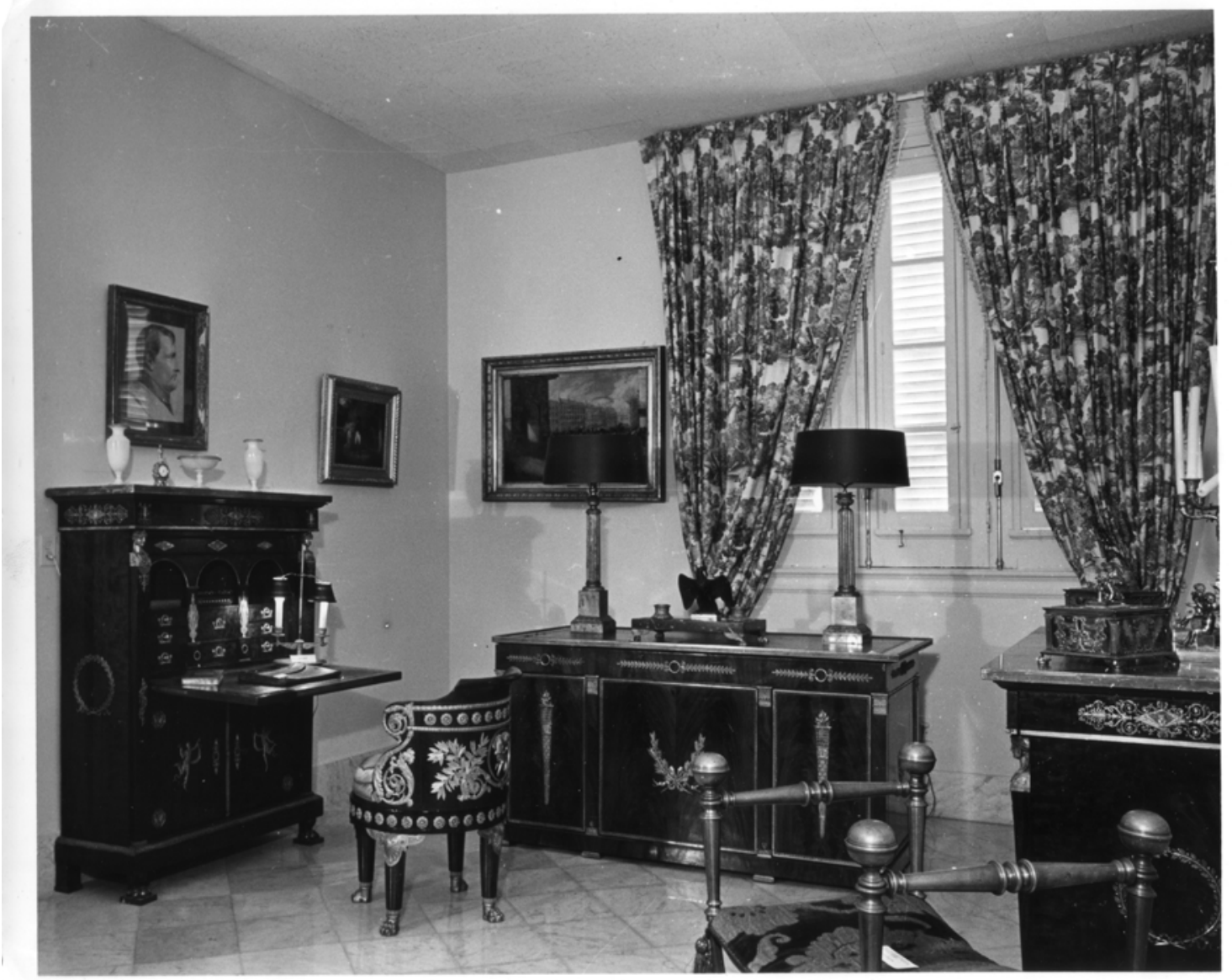

Fig. 7. Fotografía de uno de los dormitorios de la casa de Julio Lobo con presencia del secreter en el extremo izquierdo, la cómoda con el conjunto de cofres a la derecha y otros muebles de estilo Imperio francés. La Habana, s. XX. Fuente: Archivo del Museo Napoleónico

De manera que se trata de un conjunto valioso que en el contexto habanero verifica la suntuosidad de otra cultura que no resultó ajena a Cuba en materia de mobiliario. De hecho, existen algunos de mayor relevancia por su procedencia certificada a partir de investigaciones y material de archivo sobre el origen del museo, recopilados por Marta Arjona durante la recuperación de la colección privada de Julio Lobo. Hay piezas asociadas a personalidades francesas de la época como Jerónimo Bonaparte, hermano de Napoleón, y a la princesa Matilde Bonaparte, hija de Jerónimo. ${ }^{20}$

En cada sala ambientada se encuentran ejemplares relevantes. Por ejemplo, en el dormitorio, se exhiben un secreter y cómoda pertenecientes al 
Marqués de Biron, que fueron fabricados por François Xavier Heckel —importante ebanista del Imperio que ejerció en rue du Faubourg Saint-Antoine entre 1797 y 1811 - en caoba con roble (Quercus robur) enchapado, mármol y decoraciones en ormolú o bronces dorados; al tiempo que el conjunto de espejo y cofres de plata dorada tiene el sello del reconocido orfebre Jean-Baptiste-Claude Odiot (1763-1850), y se registra en planilla de inventario que fue un encargo realizado por el Emperador en 1809. Dicho conjunto que tiene como elemento indispensable el espejo está catalogado como psiqué en el documento confeccionado por Pérez y Lavastida, denominación que también empleara la investigadora santiaguera Aida Morales al decir:

El peinador o coqueta psique era de pequeño formato y se colocaba por lo general encima de otro mueble. (...) Se les denominaba «tocadores a la Duquesa" y su función era la de guardar joyas, cosméticos y otros accesorios propios de la mujer. ${ }^{21}$

Además, de reconocida autoría se encuentra un armario con estampilla "Jacob Frères rue Meslée» asociado a los renombrados ebanistas de la Casa Jacob, ${ }^{22}$ en este caso, data del período liderado por Georges Jacob II (17681803) y François-Honoré-Georges (1770-1841). La pieza realizada en caoba tiene ornamentos en bronce y presenta un exquisito trabajo en marquetería con limonero y ébano. Otro ejemplar exquisito atribuido a la Casa Jacob es el palanganero o lavabo (Fig. 8) de formas estilizadas, elaborado en mármol, con tres columnas enchapadas en caoba, cuyas basas y capiteles están rematados en bronces dorados. La pieza integra un conjunto con jofaina y aguamanil o jarra de plata dorada que perteneció a Napoleón I, quien lo obsequió al general de artillería de su ejército, Conde Aubry de Boucharderie, según se refleja en el archivo institucional.

A estas piezas se añade la prestancia de la cama en forma de góndola o en bateau a la usanza napoleónica, cuyas soluciones formales fueron asimiladas en territorios como Trinidad, Santiago de Cuba y La Habana. La cama enchapada de caoba, presenta una profusa decoración con tallas en altorrelieve y ornamentos en ormolú que recrean elementos derivados de la Antigüedad como sello de poder y por el simbolismo inherente. Entre los motivos más recurrentes se encuentran las coronas de laurel, cabezas de león y otros de carácter zoomórfico; así como estrellas, palmetas y esfinges de madera dorada, remedos del imaginario egipcio que cautivó al Emperador en su campaña militar a ese país y que quedaron reflejados en estos bienes. En general, en estos muebles del Museo Napoleónico —único de su tipo en Latinoamérica- al valor artístico que irradian los exponentes se incorporan el valor histórico y simbólico por la procedencia que describen.

Igualmente de impronta francesa, en las restantes colecciones que conforman la muestra hay ejemplos de muebles lacados, como refleja una silla lacada y calada, con respaldo trabajado en papier mâché y elementos taraceados en nácar que atesora el Museo de Arte Colonial. Este ejemplar evidencia la asunción del respaldo típico que se promovió en Francia para la sillería que incorporaba esta técnica entre las décadas de 1830 y 1860. 


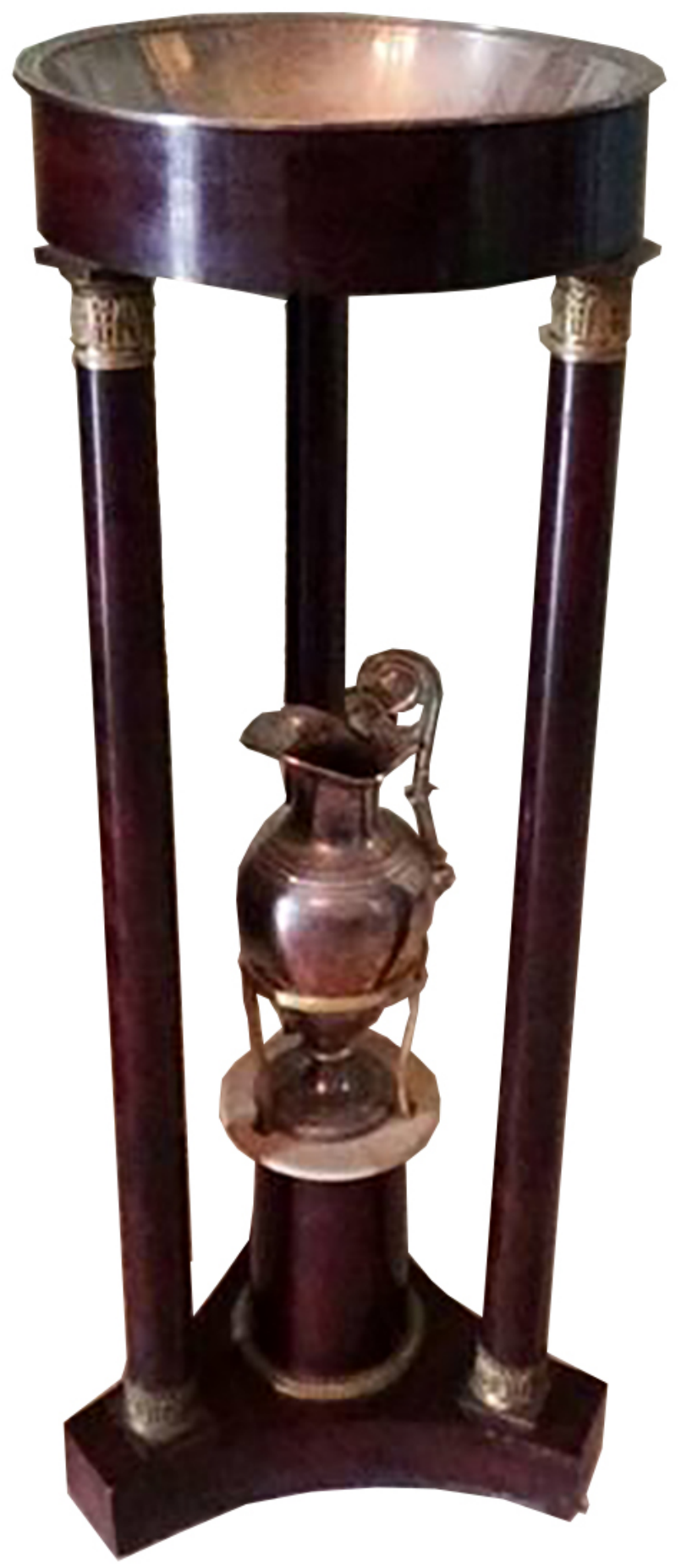

Fig. 8. Lavabo o palanganero con jofaina y aguamanil. Francia, s. XIX. Col. Museo Napoleónico

En términos de novedad en materiales y técnicas, también se exhiben en dicho museo mecedoras de madera curvada (Fig. 9). Estos arribaron a Cuba desde las últimas décadas del siglo XIX. Resulta complejo definir la casa productora en algunos casos que no conservan inscripción o estampilla, como sucede en los exponentes presentados. 

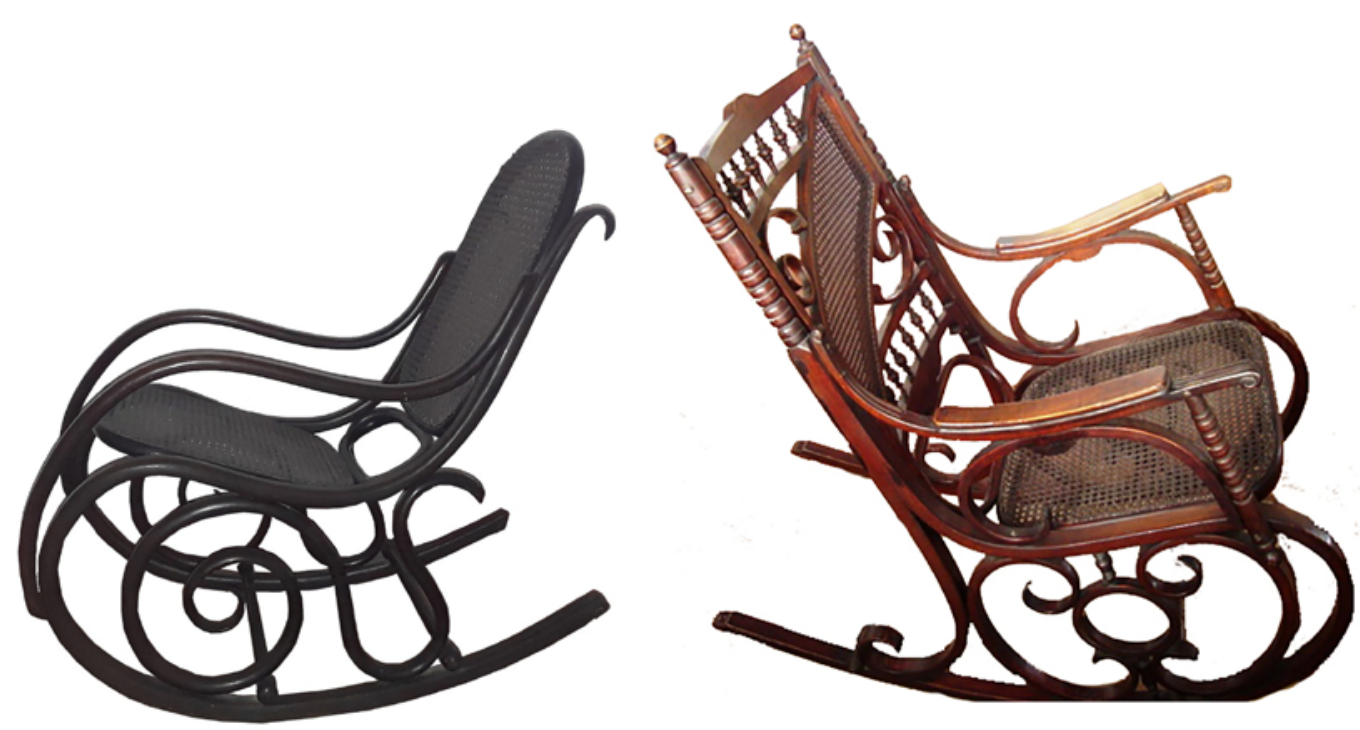

Fig. 9. Mecedora infantil de madera curvada y mecedora No. 278/21 de Jacob \& Josef Kohn. Austria-Hungría, finales s. XIX-principios s. XX. Col. Museo de Arte Colonial

Específicamente, la mecedora de la izquierda, por su altura y asiento de apenas $42 \mathrm{~cm}$ se asocia con un prototipo infantil, tomándose en cuenta la especialidad en mecedoras que había desarrollado la fábrica de Hijos de D.G. Fischel de Bohemia. No obstante, no es posible certificar fabricante, pues no se han hallado marcas visibles asociadas a algún productor. Por otra parte, la de la derecha sí corresponde a un modelo identificado desarrollado en la primera década del siglo XX por la sociedad austriaca Jacob \& Josef Kohn. ${ }^{23}$ No obstante, la procedencia específica resulta bien compleja de determinar porque esta sociedad, como sucedió en otros casos de fabricantes industriales de muebles, tenía sucursales en numerosas ciudades del orbe.

Nueva York fue una de esas ciudades donde existían casas de venta de esta fábrica europea. Dicha industria se tuvo a bien mencionar por la singularidad de la mecedora conservada en el museo habanero.

Fue justo en Nueva York, donde quedó radicado el importante ebanista alemán John Henry Belter (1804-1863). En dicha ciudad desarrolló peculiares conjuntos de sala tapizados, de tendencia Neorrococó, con palisandro (Dalbergia cearensis) y nogal. Sus piezas de profusa talla, se distinguen por la técnica del contrachapado y el predominio de motivos vegetales en el coronamiento de los respaldos.

En general, los exponentes tapizados conservados en Cuba solían ser importados, de modo que de Estados Unidos de América se introdujeron ejemplares que se exhiben en la actualidad, tanto en el Museo de la Ciudad, como en el Museo de Arte Colonial y en el Museo Municipal de Guanabacoa. En específico, el tapizado del conjunto John Henry Belter de sofá, dos sillas y dos butacas del Museo de Arte Colonial fue reemplazado en 2019 y se pudo constatar la tendencia al reaprovechamiento de telas antiguas desgastadas que se encontraron durante el proceso de restauración; así como la presencia de una inscripción casi ilegible en la tapicería original del respaldo, donde apenas puede discernirse el nombre "John" junto a otros caracteres ininteligibles a simple vista. 
De modo que una variedad de piezas procedente de los Estados Unidos de América comenzó a arribar a la Isla desde finales del siglo XVIII y se intensificó este flujo comercial en las postrimerías de la siguiente centuria. Así, pueden verificarse en este contexto varias sillas de diseño norteamericano, incluyendo un auténtico exponente de la conocida silla Windsor (Fig. 10), variante originada en Inglaterra en el primer cuarto del siglo XVIII y que fue perfeccionada en Filadelfia con maderas locales posteriormente. En esta pieza ligera de formas estilizadas se aprecia la técnica del torneado en las patas y otras estructuras constitutivas del respaldo.

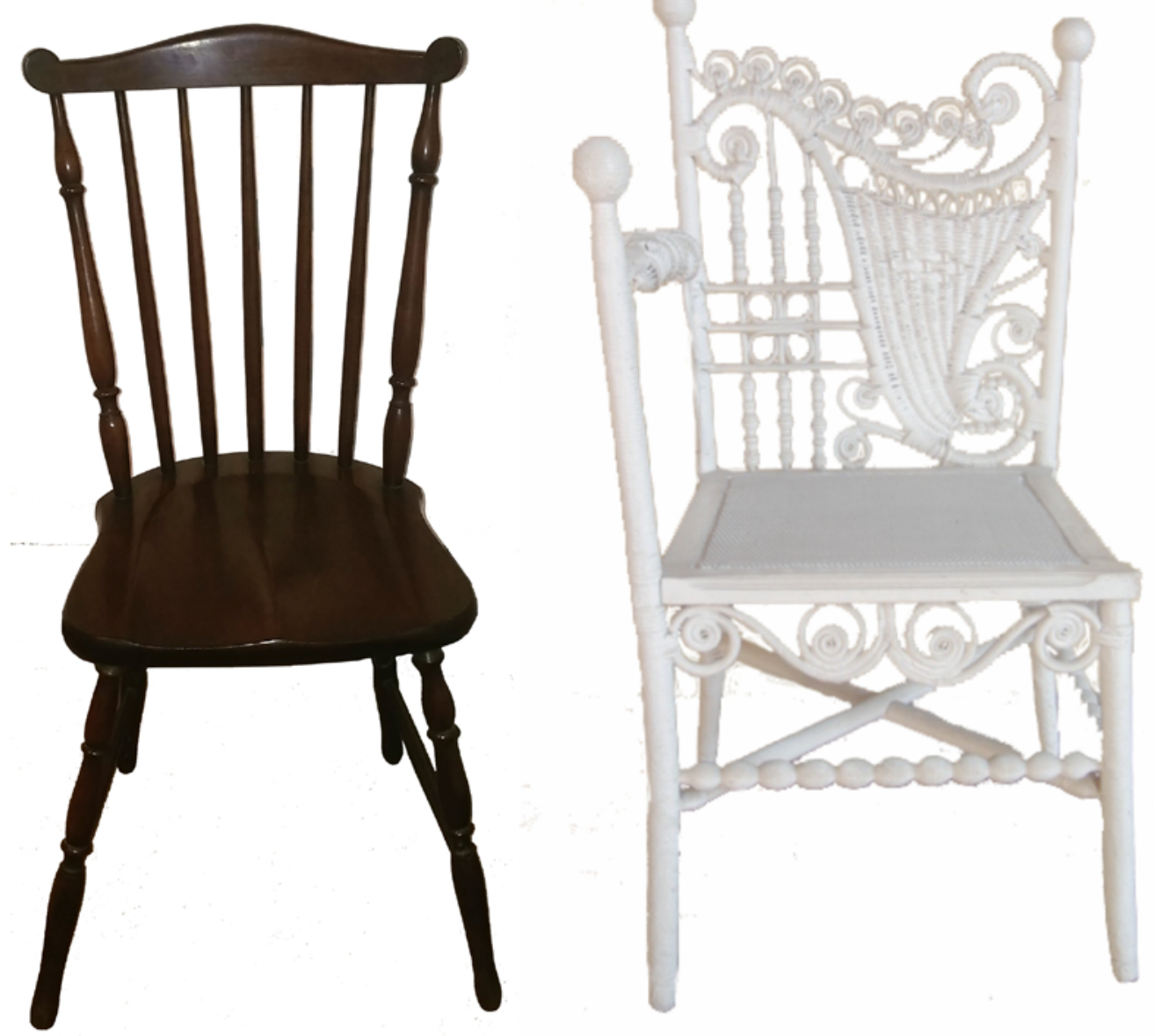

Fig. 10. Silla Windsor y butaca asimétrica de mimbre. Estados Unidos, s. XIX. Col. Museo de Arte Colonial

También por el puerto de La Habana se introdujeron desde el último tercio del siglo XIX y en las primeras décadas del XX, muebles de mimbre que tuvieron muy buena acogida gracias a la frescura del material. Se trata de objetos hermosos y ligeros que solían ubicarse en galerías para encuentros de menor formalidad o comidas habituales que no requerían la prestancia de los comedores reservados a los banquetes. Sus variantes se aprecian en representaciones de la época y además eran utilizados con frecuencia en las fotografías de estudio del período. 
Por otro lado, si bien existieron piezas importadas y copiadas en territorio insular, cobran un valor excepcional aquellas interpretaciones y adaptaciones que de estilos foráneos se hicieron en la Isla. Así, se verifica la influencia del estilo Imperio norteamericano en el devenido Imperio cubano o Imperio criollo, como también se le conoce en este escenario. Sin embargo, no se debe obviar que el original Imperio francés arribó a estas tierras, como se pudo constatar en los exponentes comentados del Museo Napoleónico y como se verifica sobre todo en la región oriental del país por la huella de los colonos franceses que emigraron fundamentalmente a esa zona.

En el caso de La Habana, los referentes del Imperio norteamericano de herencia inglesa fueron más fuertes dada la proximidad geográfica de Estados Unidos con la región occidental de la Isla. Así, las líneas curvas, gráciles y la sobriedad primaron en la interpretación criolla que vistió los hogares de Occidente sobre todo durante la primera mitad del siglo XIX. Se proyecta pues, una versión comedida y elegante del estilo con piezas realizadas en caoba, utilización constante de la rejilla muy apropiada por las altas temperaturas, y con técnicas como el enchapado, la talla, las terminaciones de los reposabrazos en volutas o soluciones espirales, y la asunción de motivos decorativos de ascendencia clásica, tales como la lira o el ánfora.

Sin embargo, Norteamérica no fue la única región del continente que irradió hacia Cuba las tendencias en materia de moblaje. La intensificación del trasiego intercolonial desde finales del siglo XVIII favoreció la introducción de materiales y muebles de otros puertos del virreinato de Nueva España. Uno conservado en museos cubanos que ejemplifica la impronta de otros territorios americanos, específicamente de México, es la butaca de Campeche (Fig. 11).

Respecto a los exponentes exhibidos en el comedor ambientado del Museo de Arte Colonial, son realizados en caoba y vaqueta con reposabrazos anchos terminados en voluta, travesaño torneado y singular presencia de orejas en los laterales del respaldo. Por sus características formales, exquisita factura y materiales, se considera que hayan sido asientos de uso masculino pertenecientes a figuras con un alto estatus económico. No obstante, se estima que de manera general esta tipología en la Isla fue adaptada, ya que, según las búsquedas bibliográficas realizadas y el intercambio con la Dra. Mercedes J. Hernández Padilla, las orejas es una peculiaridad de las piezas localizadas en Cuba.

A este rasgo morfológico se le adiciona la información histórica relativa a la existencia del Barrio de Campeche en La Habana colonial, conformado por aborígenes procedentes del homónimo territorio mexicano desde mediados del siglo XVI. De modo que pudiera estimarse la inclusión de orejas una aportación local, así como tampoco sería desatinado considerar una producción interna de estas piezas.

Además, debe tenerse en cuenta que, como sucede en otros contextos, los muebles no solo responden a la necesidad de uso de sus propietarios; sino que reflejan el estatus socioeconómico de su dueño. Por lo cual, acá se conservan variantes más elaboradas y otras más sencillas, pues las utilizaban diversos estratos sociales. Inclusive, en tres pasajes de la novela costumbrista Cecilia Valdés, de Cirilo Villaverde, recreada en La Habana de la primera mitad del siglo XIX, se menciona este tipo de mueble asociado a hogares humildes e, incluso, 
utilizado habitualmente en ese escenario por la abuela de la joven protagonista del relato.

Reducíase a bien poco el mueblaje, aunque en su poquedad y ruina se conocía que había visto mejores tiempos cuando nuevo. El más apetecible de la casa era una butaca de Campeche, ya coja, con orejas grandes y desvencijada. Agregábanse tres o cuatro sillas de cedro con asiento y respaldo de vaqueta, del mismo estilo, fuertes, macizas y antiquísimas. Hacía juego con ellas una rinconera de la propia madera, cuyos pies estaban labrados en forma de pezuña de sátiro, con molduras y hojas de parra. ${ }^{24}$

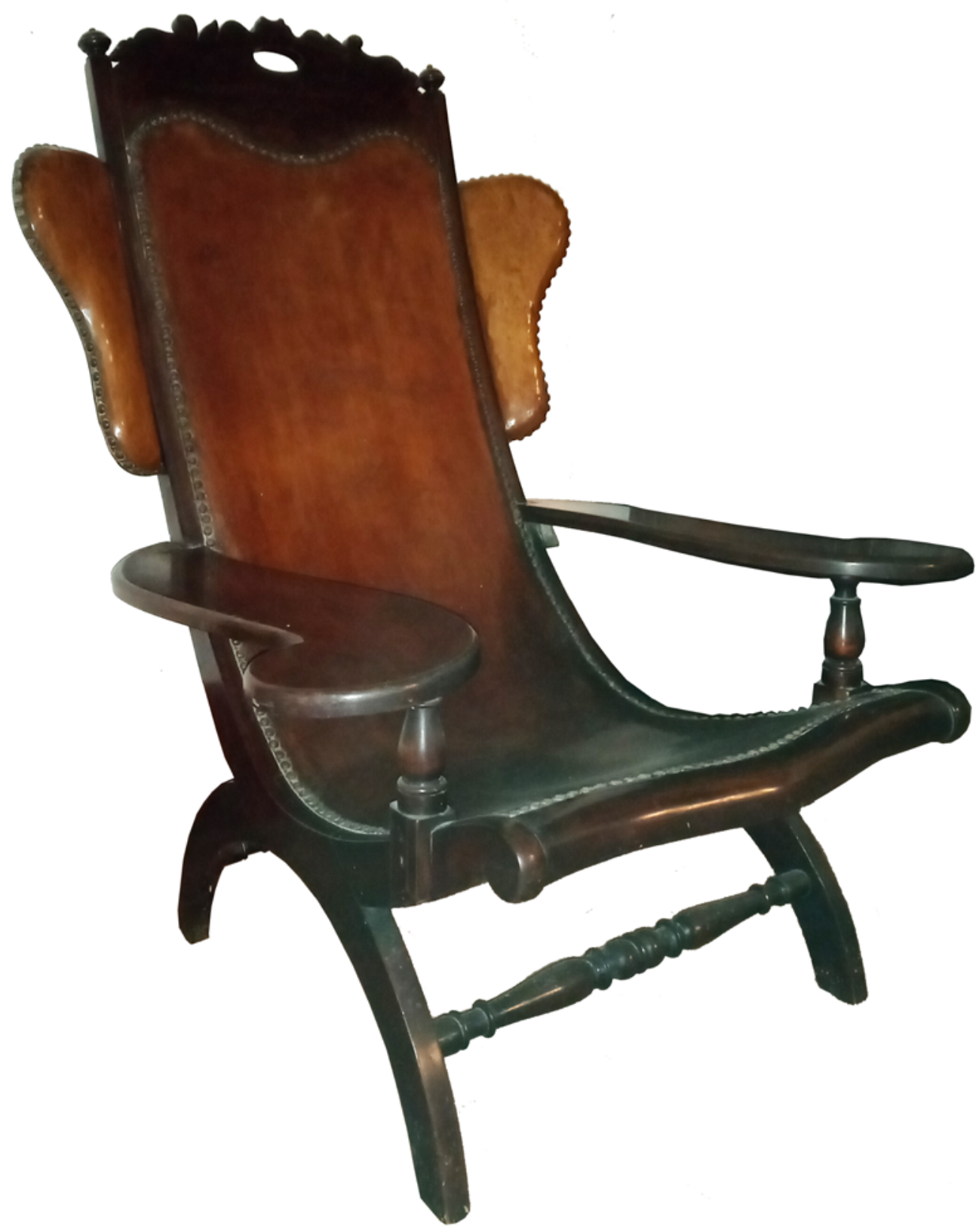

Fig. 11. Butaca de Campeche. México, s. XIX. Col. Museo de Arte Colonial 
Todos los elementos planteados conducen a afirmar que las butacas de Campeche, con origen en el butaque mexicano, se introdujeron en La Habana desde finales del siglo XVIII cuando se intensificó la exportación de estos bienes desde puertos mexicanos. Aquellas piezas es muy probable que estuvieran realizadas en la especie de caoba de aquel país (Swietenia macrophylla) ${ }^{25}$ o en cedro, y no contaban con orejas. Acá en Cuba se le incorporaron las orejas en función de la comodidad de sus propietarios que, en las altas capas sociales se suponen de uso masculino; pero en estratos más humildes podían disfrutarlo las féminas, pues se carecía de las complejidades del vestido femenino de las señoras de la alta sociedad.

En otro orden, se considera que también debió existir una producción local al interior de la Isla favorecida por el asentamiento de emigrados de la región de Campeche en La Habana, por los modelos que arribaron a este puerto y por el dominio del oficio de la ebanistería que tenían los carpinteros de ribera para la fecha.

En relación a las producciones locales que verifican la tendencia al eclecticismo pueden mencionarse la reinterpretación del estilo Luis XV, conocido en este contexto como Medallón por la forma oval de los respaldos, y los denominados Perilla, debido a la reiteración en diversas partes de las piezas del mismo motivo decorativo torneado, que se consideran una adaptación del Luis XIV. En el caso de los primeros, se trata de los ejemplares de la etapa colonial que más abundan en Cuba y que predominaron en la segunda mitad del siglo XIX. Las patas delanteras en cabriolé, el óvalo y rejilla en el asiento, así como la presencia recurrente de este material también en el respaldo, se encuentran entre las características más distintivas. Sobre los muebles Medallón, ${ }^{26}$ el restaurador e investigador cubano Javier León, afirma que se constatan tres patrones: piezas importadas de Estados Unidos con maderas foráneas y soluciones más complejas favorecidas por el desarrollo tecnológico, otras de hechura local artesanal con decoraciones en bajo y huecorrelieve e incisiones, y un patrón híbrido que ensambla elementos industriales de producción norteamericana con otros artesanales realizados en Cuba.

Respecto a los muebles Perilla (Fig. 12), como analizara Anita Arroyo ${ }^{27}$ -investigadora pionera del ramo en $\mathrm{Cuba}$-, reflejan una reinterpretación del estilo Luis XIV. De manera que los altos respaldos, el dorado, el tapizado, las patas rectas, formas rígidas y talla excesiva del estilo francés, fueron adaptados en función del clima, de la tecnología, de los materiales entre los que predominaron la majagua, la caoba y la rejilla, y también debido al propio gusto estético insular.

Estas piezas presentes en Cuba desde finales del XIX, se popularizaron durante las primeras décadas de la siguiente centuria y representan en Cuba el tránsito del mobiliario artesanal a la vertiente industrial que, además de acelerar, aumentar la producción y simplificar el trabajo; abarató los costos y favoreció la adquisición de estos bienes por la clase media, sobre todo en la etapa republicana. Por fortuna, aún se conservan juegos de sala, dormitorio y comedor en viviendas de Trinidad, en la provincia Sancti Spíritus, y en algunos museos cubanos. Así, las colecciones de las instituciones museales incluidas en el análisis evidencian la riqueza artística y diversidad de orígenes del mueble en el período. 


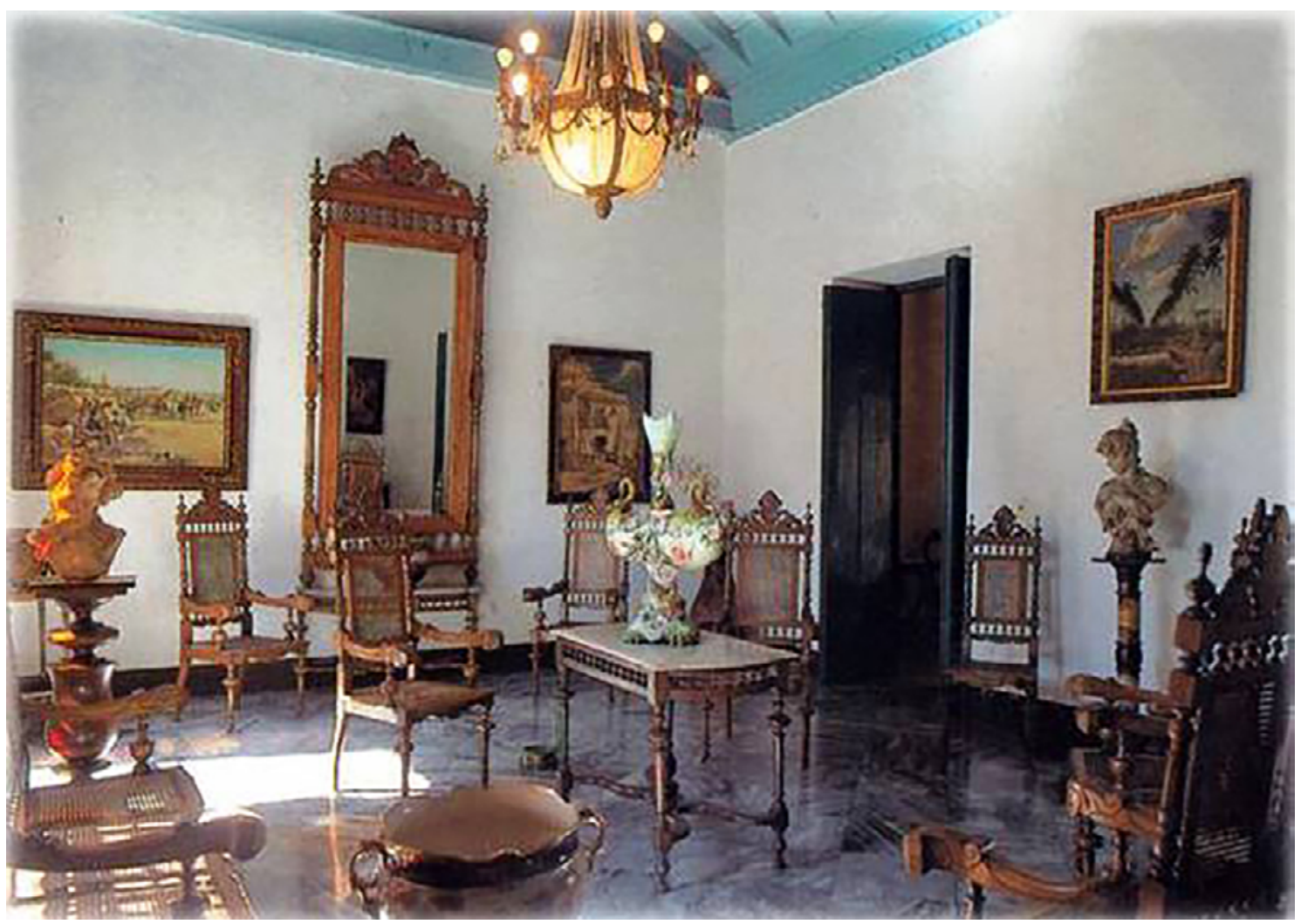

Fig. 12 Sala ambientada con conjunto de muebles Perilla. Cuba, finales s. XIX-principios s. XX. Fuente: Archivo del Museo Municipal de Guanabacoa

\section{Conclusiones}

El contexto cultural internacional de la segunda mitad del siglo XVIII, como se ha demostrado, tuvo una notable repercusión durante la centuria siguiente y, junto a condiciones favorables internas, influyó en la adopción y desarrollo de un mobiliario diverso en el escenario cubano del siglo XIX.

En términos de estilo, aunque existen piezas representativas de estilos puros, prima el eclecticismo arraigado en el gusto de la sociedad decimonónica que manifiesta los revivals de estilos precedentes. De una parte, los materiales más recurrentes son la caoba y el cedro, aunque hay presencia de otras maderas oriundas de Cuba y foráneas, por el acentuado intercambio comercial que existió durante el siglo XIX. Por otra parte, respecto a las técnicas, se aprecian las tallas a relieve, el torneado, el enchapado, el calado, la incisión, la taracea, el ormolú y otras que manifiestan la riqueza formal de los exponentes.

En general, las piezas conservadas en los cinco museos señalados de La Habana demuestran la pluralidad de procedencias geográficas e improntas culturales de naciones como España, México, Estados Unidos, Francia y otros países europeos. La huella de territorios foráneos se manifestó de variadas formas, entre las que destacan la introducción de estilos y tipos de muebles que fueron preservados, imitados o reinterpretados localmente por artesanos criollos. De modo que La Habana del siglo XIX se convirtió en receptáculo por excelencia de la diversidad y riqueza de esta expresión de la cultura material. 


\section{NOTAS}

${ }^{1}$ La Casa de la Obra Pía está situada en calle Obrapía, no. 158 e/ Mercaderes y San Ignacio, el Museo de Arte Colonial en calle San Ignacio, no. 61, Plaza de la Catedral, y el Museo de la Ciudad en calle Tacón, no. 1 e/ Obispo y O'Reilly, Plaza de Armas; los tres en La Habana Vieja, Cuba. Por otro lado, el Museo Municipal de Guanabacoa está ubicado en las afueras del Centro Histórico, específicamente en calle Martí, no. 108 esq. a Versalles, Guanabacoa, y el Museo Napoleónico se encuentra en Calle San Miguel, no. 1159 esq. a Ronda, en el municipio habanero Plaza de la Revolución.

${ }^{2}$ Lilia Martín Brito, "El dujo cubano," Universidad y Sociedad 12, no. 1 (Enero 2020): 33-39.

${ }^{3}$ El término bargueño quedó expresado por el historiador español Juan Facundo Riaño en 1872, en el Catálogo de objetos artísticos españoles, para referirse a un particular tipo de escritorio del Renacimiento y Barroco español que consideraba tuvo su origen en Bargas desde el siglo XVI. El vocablo, inclusive, llegó a ser reconocido por la Real Academia Española en 1914. No obstante, la denominación no cuenta con un respaldo histórico ni científico y, por tanto, desde mediados del siglo XX se generaron debates en torno a su empleo. En la actualidad, resulta ineludible mencionar la exhaustiva investigación de la Dra. María Paz Aguiló sobre las variantes de esta tipología, que la comunidad científica ha tenido a bien en llamar escritorios de Salamanca — principal centro productor - o escritorios de columnillas. Para más información sobre esta tipología y otros muebles en el contexto español, consúltese María Paz Aguiló Alonso, El mueble en España, siglos XVI-XVII (Madrid: Antiquaria, 1993).

${ }^{4}$ Ovidio Ortega, Yamilé Luguera, y César Alonso, "El comercio en el puerto de La Habana durante el siglo XIX y el naufragio de la goleta Arrow," Boletín del Gabinete de Arqueología, no. 6 (2007): 72.

${ }^{5}$ La conocida en Cuba como butaca de Campeche o campechana, se considera tuvo su origen en el butaque mexicano. Se trata de piezas estructuralmente muy similares que han sido objeto de estudio en países como los Estados Unidos y, en el propio México, la Dra. Mercedes J. Hernández Padilla le ha dedicado un análisis en la comunicación para el III Congreso Iberoamericano de Historia del Mueble titulada: El butaque. De asiento popular a arquetipo del mueble mexicano del siglo XX. Precisamente, en intercambio profesional con dicha investigadora, explicaba que desde 1780 se intensificó la exportación de estos bienes muebles hacia territorios como Cádiz, La Habana y Nueva Orleáns, entre otros. Una curiosidad histórica es que específicamente en La Habana, desde mediados del siglo XVI, se ubicaba el Barrio de Campeche en el este de la antigua ciudad amurallada. Área donde tempranamente se asentaron aborígenes yucatecos procedentes de Campeche como resultado del tráfico forzado. Sobre este particular, consúltese Karen Mahé, Lugo Romera, y Sonia Menéndez Castro, Barrio de Campeche: tres estudios arqueológicos (27) (La Habana: Fundación Fernando Ortiz, 2003).

${ }^{6}$ María Mercedes Fernández Martín, "Mobiliario e interiores cubanos durante la presencia española," Laboratorio de Arte, no. 25 (2013): 551. Para una aproximación más cercana a modelos de mobiliario inglés que arribaron a Cuba, consúltese Thomas Chippendale, The Gentleman and Cabinet-Maker's Director (London: impreso por el autor, 1754).

${ }^{7}$ El Aviso. Papel Periodico de la Havana [sic], no. 255 (jueves 15 de enero de 1807): 4.

${ }^{8}$ Paul Mantoux, La Revolución Industrial en el siglo XVIII. Ensayo sobre los comienzos de la gran industria moderna en Inglaterra (Madrid: Aguilar, S. A., 1962), 8.

${ }^{9}$ Aquiles Gay y Lidia Samar, El diseño industrial en la historia (Córdoba: Ediciones tec, 2007), 42.

${ }^{10}$ Para más información sobre los fabricantes de muebles en madera curvada, consúltense los blogs http://www.muebledeviena.com/y https://www.fundaciocaixavinaros.com/cataleg/ blog-sobre-moble-corbat-vienal, del reconocido investigador español Julio Vives Chillida y de la Fundació Caixa Vinaròs, respectivamente. 
${ }^{11}$ Zoila Lapique Becali, La memoria en las piedras (Ciudad de La Habana: Ediciones Boloña, 2002), 19.

${ }^{12}$ Alejandro de Humboldt, Ensayo político sobre la Isla de Cuba (Ciudad de La Habana: Oficina del Historiador de la Ciudad de La Habana, 1959), 205.

${ }^{13}$ Jacobo de la Pezuela, Diccionario geográfico, estadístico, histórico, de la Isla de Cuba (Vol. 2) (Madrid: Imprenta del Establecimiento de Mellado, 1863), 45.

${ }^{14}$ Marial Iglesias Utset, Las metáforas del cambio en la vida cotidiana: Cuba 1898-1902 (Ciudad de La Habana: Ediciones UNIÓN, 2003), 43-44.

${ }^{15}$ Alicia García Santana, Las primeras villas de Cuba (Ciudad de Guatemala: Ediciones Polymita, 2008), 315.

${ }^{16}$ Lilia Martín Brito, "El mueble de los siglos XVI y XVII en Cuba," Res Mobilis 5, no. 6 (I) (2016): 56-75.

${ }^{17}$ Yenis Noa Ramírez, "Colección de muebles del salón dormitorio Museo Casa de la Obrapía. Sus valores histórico artísticos" (Tesis de Pregrado, Colegio Universitario San Gerónimo de La Habana-Universidad de La Habana, 2015), 110-113.

${ }^{18}$ Orlando Castellanos, "El poeta en dos tiempos," La Jiribilla, 2002, http://www.lajiribilla. co.cu/2002/n44 marzo/1157 44.html.

${ }^{19}$ Gema Pérez y Natalia Lavastida, Museo Napoleónico (La Habana: Editorial Letras Cubanas, 1986).

${ }^{20}$ Las planillas de inventario del museo, conformadas a partir de la documentación recuperada de la colección de Julio Lobo, son la principal fuente que refleja el trayecto de estos muebles en diferentes períodos. Por otra parte, entendidos en el tema como Luke Dalla Bona, pertenecientes a la Sociedad Napoleónica Internacional (INS), han contribuido a esclarecer y enriquecer la información sobre los orígenes de algunos exponentes. A la vez, en la Isla se han desarrollado estudios puntuales sobre segmentos de esta colección, entre los que cabe destacar Francis Natacha Cruz Aguiar, "Los muebles JACOB del Museo Napoleónico," Revista de la Biblioteca Nacional José Martí 32, no. 1 (1959): 159-176.

${ }^{21}$ Aida Liliana Morales Tejeda, El signo francés en Santiago de Cuba: espacios, ajuares y ritos de los grupos sociales privilegiados (1830-1868) (Santiago de Cuba: Editorial Oriente, 2015), 131-132.

${ }^{22}$ Para más información sobre el tema consúltese Cruz Aguiar, "Los muebles JACOB del Museo Napoleónico", 159-176.

${ }^{23}$ El blog de Julio Vives Chillida contiene útil y variada información sobre este tipo de muebles. Asimismo, pueden consultarse catálogos de fabricante por años como el de 1902 y el de 1910 de Jacob \& Josef Kohn.

${ }^{24}$ Cirilo Villaverde, Cecilia Valdés (La Habana: Letras Cubanas, 2005), 30-31.

${ }^{25}$ Sobre las especies y usos recurrentes de las maderas de México consúltese Programa de las Naciones Unidas para el Desarrollo México, Catálogo de Maderas Tropicales de México del Proyecto Biodiversidad en Bosques de Producción y Mercados Certificados, 2012, http://www. conabio.gob.mx/institucion/proyectos/resultados/J084 Fichas\%20de\%20Especies.pdf.

${ }^{26}$ Javier León Valdés, "El mueble Medallón en Cuba (1830-1870): un estudio de caso en Sancti Spíritus" (Tesis de Maestría, Universidad de las Artes, Centro de Estudios Conservación, Restauración y Museología, 2016).

${ }^{27}$ Anita Arroyo, "La Madera," en Las artes industriales en Cuba. Su historia y evolución desde las culturas precolombinas hasta nuestros días (La Habana: Cultural, S. A., 1943), 95-180. 